\title{
Detection of HPV Positivity by Immunohistochemistry in Colposcopic Cervical Biopsies with a Cytological Diagnosis of ASCUS
}

\author{
ASCUS Tanısı Olan Hastaların Kolposkopik Biyopsi \\ Örneklerinde İmmünohistokimyasal Olarak Human Papilloma \\ Virüs Pozitifliğinin Araştırılması
}

\author{
Güldeniz AKSAN DESTELI' ', Ebru DEMIRALAY², Türkan GÜRSU1', Ali AYHAN³
}

Departments of ' Obstetrics and Gynecology and ' $P$ Pathology, Başkent University, Faculty of Medicine, ISTANBUL, TURKEY ${ }^{3}$ Departments of Obstetrics and Gynecology, Başkent University, Faculty of Medicine, ANKARA, TURKEY

\begin{abstract}
Objective: Many epidemiological studies have shown that human papillomavirus related infections play a major role in cervical preinvasive and invasive lesions. ASCUS (atypical cells of undetermined significance) observed in about $4-5 \%$ of all cervical cytology specimens. We searched for the presence of HPV with immunohistochemical methods in the biopsy material of patients diagnosed with ASCUS using cytology.
\end{abstract}

Material and Method: The colposcopic biopsy or Loop Electro Excisional Procedure (LEEP) material of 115 patients with a diagnosis of ASCUS were evaluated. HPV (type 6,11,16,18,31,33,42,51,52,56 and 58) immunohistochemistry was applied to all materials. The relationship between the biopsy results and HPV positivity was investigated.

Results: Cervical intraepithelial neoplasia (CIN) I was found in $34.8 \%$, CIN II in $13 \%$ and CIN III in $9.6 \%$ of the patients and cervicitis was present in $42.6 \%$ of the patients. HPV immunohistochemistry was positive in 11 cases $(9.6 \%)$ and no staining was seen in 104 cases (90.4\%). No positive staining was seen in the chronic cervicitis cases. The rate of positive staining was $15 \%(6 / 34)$ in the CIN I diagnosed group, $20 \%(3 / 12)$ in the CIN II diagnosed group and $18.2 \%(2 / 9)$ in the CIN III diagnosed group.

Conclusion: HPV positivity was found to be lower compared to the literature both in total and in cases diagnosed by biopsy. No staining occurred in any patient with cervicitis. In conclusion, we believe that immunohistochemical examination is not an appropriate method for the determination of HPV.

Key Words: Cervix uteri, Colposcopy, Cervical intraepithelial neoplasia, Human papilloma virus, Immunohistochemistry
ÖZ

Amaç: Yapılan birçok epidemiyolojik çalışmada human papilloma virüse bağlı enfeksiyonların servikal preinvaziv ve invaziv lezyonlarda başlıca rolü oynadığı ispatlanmıştır. ASCUS (atypical cells of undetermined significance) tüm servikal sitolojilerin yaklaşık \%4-5'inde saptanır. Bu çalışmada sitolojide ASCUS tanısı almış ve kolposkopik biyopsi uygulanmış hastaların biyopsi materyallerinde immünohistokimyasal olarak HPV varlığı araştırıldı.

Gereç ve Yöntem: 115 ASCUS tanısı alan hastanın kolposkopik biyopsi ve/veya Loop Electro Excisional Procedure (LEEP) materyalleri değerlendirildi. Tüm materyallere immünohistokimyasal olarak HPV (tip 6,11,16,18,31,33,42,51,52,56 ve 58) uyguland. Biyopsi sonuçları ile HPV pozitifliği arasındaki ilişki araştırıldı.

Bulgular: Çalışma grubundaki hastaların \%34,8'inde CIN (Servikal intraepitelyal neoplazi) I, \%13'ünde CIN II, \% 9,6’sinda CIN III, \% 42,6'sında servisit saptand. Olguların 11'inde (\% 9,6) HPV immünohistokimyası pozitif olup, 104'ünde (\% 90,4) boyanma görülmedi. Kronik servisitlerde pozitif boyanma görülmedi. CIN I tanılı grupta pozitif boyanma oranı $\% 15$ (6/34), CIN II tanılı grupta $\% 20(3 / 12)$ ve CIN III tanılı grupta \%18,2 (2/9) idi.

Sonuç: Çalışmamızda, HPV pozitifliği hem toplamda, hem de biyopsi ile tanımlanmış CIN olgularında literatürde verilen rakamlara göre oldukça düşüktür. Ancak servisit olgularının hiçbirinde boyanma olmamıştır. Sonuç olarak immünohistokimyasal incelemenin HPV tespitinde kullanılmasının uygun bir teknik olmadığı düşünülmüştür.

Anahtar Sözcükler: Serviks uteri, Kolposkopi, Servikal intraepitelyal neoplazi, İnsan papilloma virüsü, İmmünohistokimya

Correspondence: Guldeniz AKSAN DESTELİ

Başkent Üniversitesi, Tip Fakültesi, Kadın Hastalıkları ve Doğum AD,

Oymacı Caddesi, No:2, 34662, Altunizade, İSTANBUL, TURKEY

E-mail: guldenizdesteli@hotmail.com Phone: +90 2165541500 


\section{INTRODUCTION}

Cytology-based screening programs are widely used in the diagnosis of cervical precancerous lesions and significantly decrease the incidence of cervical cancer (1). Human papilloma virus (HPV) related infections have been shown to play a major role in cervical preinvasive and invasive lesions in many epidemiological studies $(2,3)$. Inclusion of the PCR (polymerase chain reaction) HPV DNA test in cases with abnormal cytology or even in screening programs is therefore suggested.

"Atypical squamous cells of undetermined significance" (ASCUS) is seen in about 4-5\% of all cervical cytologies and is the most common pathology (4). Colposcopic evaluation is required in high grade cytological anomalies. However, there is no consensus on the optimal approach for ASCUS diagnosed cytologies (5). A direct colposcopic evaluation as well as smear follow-up or HPV DNA test with PCR can be performed. Spontaneous regression of low-grade lesions is likely. A higher rate of CIN 2-3 diagnosis was reported to be made with colposcopy in patients diagnosed with ASCUS who were found be positive with the HPV DNA test before colposcopy and biopsy (6). The DNA test in fluid-based cytologies was reported to decrease the need for colposcopy by $40-60 \%$ in some studies $(7,8)$. While high-risk (HR) HPV DNA positivity in ASCUS diagnosed cytologies was $43 \%$, the incidence of CIN 2 and above lesions was $10.3 \%$ and the place of the HR HPV DNA test in ASCUS diagnosed cytologies could therefore be limited (8,9). HPV 16 and 18 are responsible for about $70 \%$ of cervical cancers and HPV genotyping has therefore been thought to be potentially useful in the distinction of the group at risk in terms of CIN 2 and above lesions $(10,11)$.

We wanted to evaluate the relationship between the biopsy results and HPV positivity by applying immunohistochemical HPV staining as it is more practical and cheaper than PCR and to show colposcopy could be recommended in this group if we could demonstrate the presence of such a relationship in this study .

\section{MATERIAL and METHOD}

We included patients with a result of ASCUS on smear and who had undergone a colposcopic biopsy between January 2009 and June 2013 in the study. The pathology of 162 patients was ASCUS between these dates. Some of these patients were only followed-up with smears. They did not require colposcopy as no abnormal cytology was found in the follow-ups. The HR HPV DNA test was performed on the cervical smear for a few but colposcopy was not needed as the result was negative. There were 30 such patients.
The remaining 132 patients underwent colposcopic biopsy while LEEP (Loop Electro Excisional Procedure) was used directly in some patients as they were suspicious in terms of a high-grade lesion. A group of patients underwent LEEP due to their biopsy diagnosis of CIN2-3.

Biopsy material was accessed and/or found appropriate for staining in 115 of the 132 patients. Colposcopic biopsy and/ or LEEP materials were studied. HPV (type 6,11,16,18,31, $33,42,51,52,56$ and 58) (Ab-3, Thermo Scientific, UK) was immunohistochemically applied to the profiles fixed in ten percent formaldehyde solution and routinely processed. The presence of cells showing nuclear staining was examined under the light microscope.

Both preparations were stained when patients had both LEEP and colposcopic biopsy material. The age, gravida and parity of all patients with a diagnosis of ASCUS were evaluated. We evaluated whether there was a relationship between the staining rates of the patients and the pathology results and age.

Statistical Analyses: The SPSS (Statistical Package for Social Sciences) for Windows 15.0 program was used for the statistical analysis of study findings. Descriptive statistical methods (Mean, Standard deviation) as well as Chi-square and Fisher's Exact test for the comparison of qualitative data were used when evaluating study data. Significance was evaluated at the level of $\mathrm{p}<0.05$

\section{RESULTS}

A total of 115 cases aged between 20 and 67 years were included in the study. The mean age was $34.54 \pm 9.42$ years. The gravida number varied between 0 and 6 ; the mean was $1.16 \pm 1.57$ and the median was 0 . The parity varied between 0 and 5 ; the mean was $0.82 \pm 1.13$ and the median 0 .

Immunohistochemistry was used for the biopsy materials of 88 (76.5\%) cases who had undergone colposcopic biopsy and $27(23.5 \%)$ cases who had undergone LEEP. Both the LEEP and colposcopic biopsy material were stained for 13 patients and the results were the same.

Evaluation of the pathology results revealed CIN 1 in 40 $(34.8 \%)$ cases, CIN 2 in 15 (13\%) cases, CIN 3 in 11 (9.6\%) cases and cervicitis in $49(42.6 \%)$ cases (Table I). HPV staining was seen in 11 cases $(9.6 \%)$ and no staining was present in 104 (90.4\%) (Figure 1,2).

A statistically significant difference was present between HPV positivity and the pathology result $(\mathrm{p}<0.05)$. The staining rate was significantly higher than for cervicitis cases ( $0 \%$ staining) in $15 \%$ of the patients diagnosed with CIN 1 , $20 \%$ of the patients with CIN 2 and $18 \%$ of the patients with 
Table I: HPV staining and diagnosis distribution

\begin{tabular}{|l|l|r|r|}
\hline \multicolumn{2}{|l|}{} & n & \% \\
\hline HPV staining & Not stained & 104 & 90.4 \\
\hline & Stained & 11 & 9.6 \\
\hline Result & CIN 1 & 40 & 34.8 \\
\hline & CIN 2 & 15 & 13 \\
\hline & CIN 3 & 11 & 9.6 \\
\hline & Cervisit & 49 & 42.6 \\
\hline
\end{tabular}

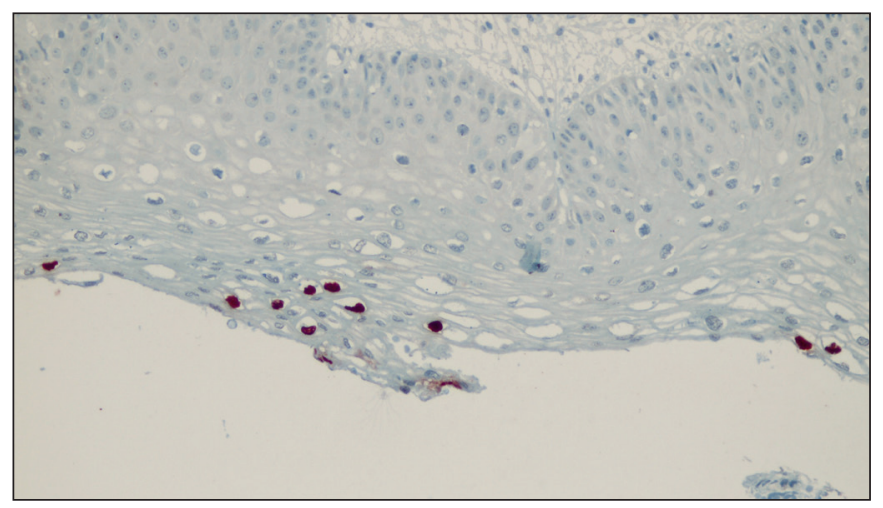

Figure 1: Strong positive staining with HPV in epithelial cell nuclei immunohistochemically in a case diagnosed with CIN I (HPV; x100).

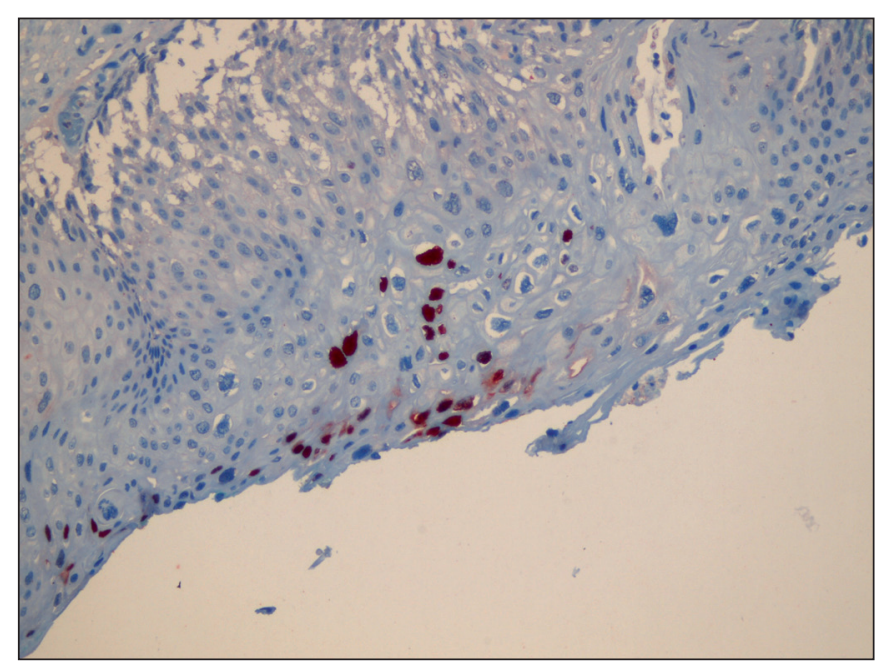

Figure 2: Strong positive staining with HPV in epithelial cell nuclei immunohistochemically in a case diagnosed with CIN III (HPV; x100).

CIN 3. However, no statistically significant difference was present between the staining rates in CIN 1, CIN 2 and CIN 3. When considering CIN cases with staining, $54.5 \%$ were CIN 1, 27.3\% CIN-2 and 18.3\% CIN-3. The HPV staining rate in the CIN2+CIN3 group (5/21, 19.2\%) was higher than in the CIN1 + Cervicitis group (6.7\%) but difference was not statistically significant ( $p>0.05$ ) (Table II).

A statistically significant difference was present between the rates of HPV staining according age group $(\mathrm{p}<0.05)$. The HPV staining rate was $19 \%$ in cases aged $21-29$ years and $4.1 \%$ in those aged 30 years or more (Table III).

Evaluation of pathology results by age group showed a higher HPV staining rate (36.4\%) in the CIN2+CIN3 cases than the CIN1 + Cervicitis cases (12.9\%) in the 21-29 years age group but this difference was not statistically significant $(\mathrm{p}>0.05)$.

Table II: Distribution of diagnosis according to the staining results

\begin{tabular}{|c|c|c|c|}
\hline \multirow{3}{*}{ Result } & \multicolumn{2}{|c|}{ HPV Staining } & \multirow{3}{*}{$\mathbf{p}$} \\
\hline & Not stained & Stained & \\
\hline & n (\%) & n (\%) & \\
\hline Cervisit + CIN 1 & $83(93.3 \%)$ & $6(6.7 \%)$ & \multirow{2}{*}{$0,12^{\star}$} \\
\hline CIN 2 + CIN 3 & $21(80.8 \%)$ & $5(19.2 \%)$ & \\
\hline
\end{tabular}

Fisher's Exact test, ${ }^{*} p>0.05$

Table III: HPV staining by age

\begin{tabular}{|c|c|c|c|}
\hline \multirow{3}{*}{ Age } & \multicolumn{2}{|c|}{ HPV Staining } & \multirow{3}{*}{$\mathbf{p}$} \\
\hline & Not stained & Stained & \\
\hline & n (\%) & n (\%) & \\
\hline 21-29 & $34(81.0 \%)$ & $8(19.0 \%)$ & \\
\hline 30 and over & $70(95.9 \%)$ & $3(4.1 \%)$ & $0.01)^{n}$ \\
\hline
\end{tabular}

Fisher's Exact test, ${ }^{*} p<0.05$

\section{DISCUSSION}

The HPV prevalence is highest in the 15-25 years age group at about $25-40 \%$ and tends to decrease gradually afterwards (12). We found HPV positivity to be significantly higher between the ages of 21 to 29 years compared to those over 30. This information is consistent with the literature. Biopsy results of the ASCUS diagnosed cases were CIN-1 in $34.8 \%$, CIN-2 in $13 \%$, CIN-3 in $9.6 \%$ in our study where we investigated the role of HPV immunohistochemistry in the diagnosis. The total rate of CIN $2+3$ in ASCUS diagnosed cytologies has been reported as $10.3 \%$ in other publications $(8,9)$. The ATHENA study reported biopsy results of $10 \%$ for CIN-1, 2.2\% for CIN 2 and 2.9\% for CIN 3 (11). We believe the CIN 2/3 rate (19.6\%) was high in our study as all ASCUS diagnosed patients did not undergo biopsy and some were followed-up with smears. 
Various methods with various sensitivity and specificities are available for the detection of high-risk HPV. Studies have usually been performed using PCR-based techniques in recent years. The immunohistochemistry method is cheaper than PCR.

Syrjanen et al. found the HPV positivity with immunochemistry to be $100 \%$ in cervical papillomatous lesions (13). Cho et al. found a positivity of $55.6 \%$ in cervical carcinoma. PCR and HPV positivity was found to be $100 \%$ in these cases (14). Yildiz et al. found a positivity rate of $48.6 \%$ in the immunohistochemical study they conducted with p16 in cervical squamous lesions. HR HPV positivity was present in $31.4 \%$ of the cases (15). Pavai et al. examined HR HPV positivity with PCR and immunohistochemistry in 10 LSIL, 18 HSIL and 30 cervical cancer cases. Positivity was found in $66.6 \%$ and $50 \%$ of carcinoma cases with PCR and immunohistochemistry respectively, while the same rates were $46.4 \%$ and $57.1 \%$ for the dysplasia group. Anticapsid antibody and anti E6 antibody were used in the immunohistochemical study. While staining with anticapsid antibody was seen in 3 cases in the CIN 1 (LSIL) group and in 3 cases in the CIN2 and CIN 3 (HSIL) group, no staining was seen in the carcinoma group. In cases that stained with the E6-E7 antibody as shown with thiamine amplification, positivity was found in all 3 LSIL cases that stained with anticapsid antibody and the staining rate was quite high in the HSIL and carcinoma cases. However, the evaluation was reported to be difficult due to the strong background staining (16). Likewise, Melsheimer et al. found loss of the viral L1 capsid antigen in HSIL in their study (17). The low rate of staining in our study is consistent with this as we used an anticapsid antibody.

Immunohistochemical HPV positivity was found in 9.6\% of the biopsy samples diagnosed with ASCUS in our study. HPV positivity rates in CIN $1 / 2 / 3$ cases were $15 \%, 20 \%$ and $18.2 \%$ respectively. No staining was observed in any cervicitis case. High-risk HPV DNA positivity was 32.6\% in patients diagnosed with ASCUS in a study conducted by Stoler et al. with the Cobas 4800 HPV Test (Roche Molecular Systems, Pleasanton, CA). This rate was $8.2 \%$ for HPV 16 and $2.9 \%$ for HPV 18. No CIN was found in the biopsy of $8 \%$ of the HPV $16 / 18$ positive cases. HPV 16/18 positivity was $18 \%$ in CIN 1 cases, 55\% in CIN 2 cases and 61\% in CIN 3 cases confirmed with biopsy (11). The HPV positivity with immunohistochemistry rates in our study are much lower than the literature rates both for the total and the CIN cases defined with biopsy. However, there was no staining in any cervicitis case. The low staining rates can be explained with the DNA damage that may have occurred during the routine tissue follow-up due to the retrospective nature of the study. Walboomers et al. explained the HPV-negative cancer cases in their PCR study by erroneous negativity or excessive DNA degradation (18). We also believe the lack of integration into the genome of the anticapsid antibody developing against the viral capsid could lead to very low immunohistochemical positivity rates.

Our plan was to evaluate immunohistochemical HPV determination in ASCUS diagnosed smears and accordingly recommend colposcopy in this group only. However, it is impossible to make such a a recommendation according to the current study as the immunohistochemical positivity rates were quite low. In conclusion, the use of the immunohistochemistry method and the HPV anticapsid antibody in particular cannot be said to be an appropriate approach for HPV determination in biopsies.

\section{REFERENCES}

1. Gustafsson L, Ponten J, Zack M, Adami HO. International incidence rates of invasive cervical cancer after introduction of cytological screening. Cancer Causes Control. 1997;8:755-63.

2. Bosch FX, Manos MM, Munoz N,Sherman M, Jansen AM, Peto J, Schiffman MH, Moreno V, Kurman R, Shah KV. Prevalence of human papillomavirus in cervical cancer: A worldwide perspective. International Biological Study on Cervical Cancer (IBSCC) Study Group. J Natl Cancer Inst. 1995;87:796-802.

3. Nobbenhuis MA, Walboomers JM, Helmerhost TJ, Rozendaal L, Remmink AJ, Risse EK, Van der Linden HC, Voorhorst FJ, Kenemans P, Meijer CJ. Relation of human papilloma virus status to cervical lesions and consequences for cervical-cancer screening: A prospective study. Lancet. 1999;354:20-25.

4. Solomon D, Davey D, Kurman R, Moriarty A, O’Connor D, Prey M, Raab S, Sherman M, Wilbur D, Wright T Jr, Young N; Forum Group Members; Bethesda 2001 Workshop. The 2001 Bethesda System: Terminology for reporting results of cervical cytology. JAMA. 2002;287:2114-9.

5. Arbyn M, Buntinx F, Van Ranst M, Paraskevaidis E, MartinHirsch P, Dilner J. Virologic versus cytologic triage of women with equivocal papsmears: A meta analysisof the accuracy to detect high-grade intraepithelial neoplasia. J Natl Cancer Inst. 2004;96:280-93.

6. Kececioğlu M, Seckin B, Baser E, Toğrul C, Kececioğlu TS, Cicek $\mathrm{MN}$, Gungör T. Cost and effectiveness comparasion of immediate colposcopy versus human papillomavirus DNA testing in management of atypical squamous cells of undetermined significance in Turkish Women. Asian Pac J Cancer Prev. 2013;14:511-4.

7. Kulasingam SL, Kim JJ, Lawrence WF, Mandelblatt JS, Myers ER, Schiffman M, Solomon D, Goldie SJ; ALTS Group. Costeffectiveness analysis based on the atypical squamous cells of undetermined significance/Low-grade squamous intraepithelial lesion triage Study (ALTS). J Natl Cancer Inst. 2006;98:92-100. 
8. Arbyn M, Martin -Hirsch P, Buntinx F, Van Ranst M, Paraskevaidis E, Dilner J. Triage of women with equivocal or low grade cervical cytology results: a meta analysis of the HPV test positivitiy rate. J Cell Mol Med. 2009;13:648-59.

9. Arbyn M, Paraskevaidis E, Martin -HirschP,PrendivilleW, Dilner J. Clinical utility of HPV DNA detection: Triage of minor cervical lesions, follow up women, treated for high grade CIN: An updated of pool edevidence. Gynecol Oncol. 2005;99:S7-S11.

10. De Sanjose S, Quint WG, Alemany L, GeraetsDT, Klaustermeier JE, Lloveras B, Tous S, Felix A, Bravo LE, Shin HR, Vallejos CS, de Ruiz PA, Lima MA, Guimera N, Clavero O, Alejo M, LlombartBosch A, Cheng-Yang C, Tatti SA, Kasamatsu E, Iljazovic E, Odida M, Prado R, Seoud M, Grce M, Usubutun A, Jain A, Suarez GA, Lombardi LE, Banjo A, Menéndez C, Domingo EJ, Velasco J, Nessa A, Chichareon SC, Qiao YL, Lerma E, Garland SM, Sasagawa T, Ferrera A, Hammouda D, Mariani L, Pelayo A, Steiner I, Oliva E, Meijer CJ, Al-Jassar WF, Cruz E, Wright TC, Puras A, Llave CL, Tzardi M, Agorastos T, Garcia-Barriola V, Clavel C, Ordi J, Andújar M, Castellsagué X, Sánchez GI, Nowakowski AM, Bornstein J, Muñoz N, Bosch FX; Retrospective International Surveyand HPV Time Trends Study Group. Human papillomavirus genotype attribution in invasive cervical cancer: A retrospective cross-sectional Worldwide study. Lancet Oncol. 2010;11:1048-56.

11. Stoler MH, Wright TC, Sharma A, Apple R, Gutekunst K, Wright TL; ATHENA (Adressing THE Needfor Advanced HPV Diagnostics) HPV Study Group. High risk humanpapilloma virus testing in women with ASC-US cytology. Results from the ATHENA HPV study. Am J Clin Pathol. 2011;135:468-75.
12. Herrero R, Hildesheim A, Bratti C, Sherman ME, Hutchinson M, Moraies J, Balmaceda I, Greenberg MD, Alfaro M, Burk RD, Wacholder S, Plummer M, Schiffman M. Population based study of human papilloma virus infection and cervical neoplasia in rural Costa Rica. J Natl Cancer Inst. 2000;92:464-74.

13. Syrjänen K, Väyrynen $M$, Castrén $O$, Mäntyjärvi R, Pyrhönen $S$, Yliskoski M. Yliskoski Morphological and immunohistochemical evidence of human papilloma virus (HPV) involvement in the dysplastic lesions of the uterine cervix. Int J Gynecol Obstet. 1983;21:261-9.

14. Cho NH, Kim YT, Kim JW. Correlation between G1 cyclins and HPV in the uterine cervix. Int J Gynecol Pathol. 1997;16:339-47.

15. Yildiz IZ, Usubütün A, Firat P, Ayhan A, Küçükali T. Efficiency of immunohistochemical p16 expression and HPV typing in cervical squamous intraepithelial lesion grading and review of the p16 literature. Pathol Res Pract. 2007;203(6):445-9.

16. Pavai Z, Fule T, Horvath E, Mathe M, Pap ZS, Denes L, Jung J. Comparative detection of high risk HPV $(16,18,33)$ in cervical bioptic material of Country Hospital of Tg. Mures. Rom J Morphol Embryol. 2006;47:229-34.

17. Melsheimer P, Kaul S, Dobeck S, Bastert G. Immunocytochemical detection of HPV high-risk type L1 capsid proteins in LSIL and HSIL as compared with detection of HPV L1 DNA. Acta Cytol. 2003;47:124-8.

18. Walboomers JM, Jacobs MC, Manos MM, Bosch FX, Kummer JA, Shah KV, Snijders PJ, Peto J, Meijer CJ, Munoz N. Human Papillomavirus is a necessary cause of invasive cervical cancer worldwide. J Pathol. 1999;189:12-19. 